\title{
Socio-Entropy System Approach for Analyzing of Social Forestry Management in Indonesia
}

\author{
Ismalia Afriani Hasbullah ${ }^{1 *}$, Fachrurrozie Sjarkowi², Najib Asmani², Muhammad Yazid ${ }^{2}$ \\ ${ }^{1}$ Graduate School of Sriwijaya University Palembang, Padang Selasa Street South Sumatera, Indonesia 30622 \\ ${ }^{2}$ Department of Agribusiness, Faculty of Agriculture, Sriwijaya University, Palembang, South Sumatra, Indonesia 30622
}

Received February 8, 2016/Accepted July 11, 2016

\begin{abstract}
Socio-entropy system approach (SESA) as used as a comprehensive tool to identify any kind of social shortcoming that might have constrained achievement of government policy on social-forestry. The study objectives were to observe all critical factors on the program implementation of social forestry and to analyze any intervening variables relevant to socio-psychological, socio-ecological, socio-economic, and socio-cultural shortcomings (being called here as socio-entropies) that would have been most crucial to the required policy modification. Samples were taken by purposive sampling and intensively interviewed using questionnaire. Data was analysed using structural equation modeling. The study found out that the socio-psychological entropy which apparently needs to comprehend basically relates to 3-intervening variables of self-esteem, individual compassion, and non-formal education. Likewise from the socio-ecological stand point, what need to be controled better were the spirit of owning more land plots, and the geo-morphological position of owned land plots. Meanwhile socio-economic entropy seemed to appear as consequences of people efforts in gaining more income due to hedonistic temptation and lack of knowledge about the type of environmentally sound livelihoods. Finally, the crucial factors of socio-cultural entropy were the faded away adat-law, weakening social norms, and absence of inter-ethnic but more closed, and traditional networking.
\end{abstract}

Keywords: socio-entropy, forest management, policy, adat-law, socialnorm

*Correspondence author, email: ismalia_stiper@yahoo.com,ph.: +62-85269066789

\section{Introduction}

Forest management which is vary in each management area, such as community forestry, people forests, and production forests have surely different problems and handling patterns (Westoby 1975; Wiersum 1984; Dolisca et al. 2006). Facts in the field indicate that, there are various problems encountered in forestry development programs. Public access to co-manage forest with the principle of balancing the ecological function and socio-economic functions of local communities subsistence, as well as the spirit of the forestry development programs do not run as expected. Besides other issues that must also be addressed such as boundaries, the status of land utilization distribution disparity between the local community and other parties.

The implementation of policies aimed to restore the forest functions, is expected to answer the problems in forest management. But so far people assessed that the recovery of forest function have not been able to accommodate the problems of forest management yet (Rahmat 2002). Dephutbun (2008) noted the long history of basic changes in social forestry management policy, which shows that the government has been trying to find solutions for forestry management to achieve a win-win solution for both the communities as manager and the achievement of sustainability. Instead, the community is increasingly depended on government programs and others. This causes low initiative and innovation from communities in forest management, or in other words, people become passive, dependent and weak on public aspirations in forest management (Nurtjahjawilasa et al. 2015).

Systematic effort to promote strategic management in order to sustain ecology as well as social benefits of forestry ecosystem is really a necessity of the ecosystem for the local people's welfare and at the same time it enhances functions and socio-cultural integrity, the so called 'social engineering' base on appropriate socio-anthropological consideration in an environmentally sound development of a particular ecosystem. There has been more evident indicating that forestry ecosystem provides greater intangible benefits or indirect use values relative to tangible economics benefits associated usually with direct use values (Farber et al. 2002; Pearce 2002). The intended strategic management of forestry ecosystem should really concern the importance of enhancing social as well as official responsibilities in 
functional of local, provincial, and national capacity to balance every formal and informal economic endeavor against the ecological dynamic of the ecosystem.

For the sake of efficiency and effectiveness, the strategic management must of course be relied on the more relevant and locally oriented sociological and ecological information (BMZ 1995). The so-called socio entropy system approach (SESA) as defined specifically in this study may become an effective interface for bridging information gap between social forces and ecological dynamic that threaten the invaluable natural entity of forestry ecosystem such as that of protected forest in Bukit Barisan Selatan National Park where there are systemic function in naturally environmental balance and World Heritage Cluster Mountainous Area. Failure to promote sustainable management strategy that supposedly recognizes social dimension locally would be regrettable owing to persistent social entropy that could become harmfully prevalent.

Disagreement on a macro level by Karl Marx in Soekanto (2012) exemplified by the conflict between the workers against the interests of the proletariat bourgeois which is a form of social paradox, where the discussion at the micro level is very little encountered. Sjarkowi (2014) and Veron (2001) mentioned that the failure in implementing the forestry development policies can result in the emergence of various problems which could trigger social unrest. In turn, social unrest increasingly pervasive easily ignited by provocateurs and turn into social riot. The so-called social entropy mentioned here is defined as 'negative outcome of social changes that reduced social welfare, social cohesiveness, and social responsibility those necessary to sustain ecosystem benefits following a social and economic development process that took place in regional territory (Sjarkowi 2014).

Many researches have been done to identify biogeophysical dynamic regarding forestry utilization (Bonan 2008; Claussen et al. 2001; Bala et al. 2007) but very little case of comprehensive socio-anthropology aspect of the forestry ecosystem have been observed and documented (Walt 1985: Sjarkowi 2007). In response to such information gap, the following problematic issues were taken into consideration as clear direction towards an effective field observation.

1 socio-psychological aspect. It is important to anticipate various causes of sentiment rise among residents that potentially triggering disunity.

2 a socio-ecological aspect. It is important to anticipate future trend of social conflict that might follow forestry resources crisis and environmental risks due to lack of environmental concern.

3 socio-economic aspect. It is important to identify socioeconomics interaction between the communities of different ethnicities; whether the Lampungnese or the migrants of Javanese and Sundanese interact for their earning activities within the spirit of synergism or antagonism.

4 the socio-cultural aspect. It is important to identify the prospect of social acculturation (and partnership or otherwise social conflict) that related to future intensity of natural resources harvest.
Two objectives of the study were;

1 To observe all critical factors on social forestry that might exist with respect to several-types of government programs (community forestry, people forest, production forest

2 To analyze any intervening variables relevant to sociopsychological, socio-ecological, socio-economic and socio-cultural shortcomings (called here as socioentropies) that would have been most crucial to the required policy modification.

\section{Methods}

This study was conducted in Tanggamus District Lampung Province. Determination of location of the research was based on the following criteria:

1 the first research location was community forestry area which is in the nature tourism area,

2 the second research location was the area of people forest included in the buffer area Bukit Barisan Selatan National Park (BBSNP),

3 the third research location was production forest with switched management (Figure 1). Sample among community/farmer was set up by quota sampling method on all members of quoted farm community group (gapoktan) and intensively interviewed using questionnaire with a total sample of 165 farmers.

Methods of data analysis in this study were descriptive analysis and structural equation modeling (SEM). Descriptive analysis was elaborated by indepth study to gather information relating to social entropy measurement indicators including: socio psychological, socio ecological, socio economics, and socio cultural. SEM model was intended to analyze the factors that determine the driving factor variable towards triggers of social entropy. Application used to execute models of SEM is Lisrel 8.70 (Bollen 1989).

Model goodness-of-fit was assessed using the chi-square fit index, the root mean-square error of approximation (RMSEA), and the adjusted goodness of fit index (AGFI). For a good model fit, the $\chi^{2}$ value should not be significant. The RMSEA provides an indication of the discrepancy between the observed and model generated covariance. A RMSEA value below 05 indicates a good fitting model, and values up to .08 indicate a reasonable fitting model. (Jöreskog \& Sörbom 2001). The AGFI measures how much better the model fits compared to no model at all.

SEM analysis stated as confirmatory factor analysis because the SEM analysis is more confirmatory (SEM models used had been arranged at first and more theoretical and ascertained in advance whether suitable with the data obtained or not) rather than exploratory (to find a model that fits the data); although SEM analysis techniques sometimes involve exploration in it. In addition, the preparation of latent variables of covariates manifest (manifest variables) are analogous to the technique used in the factor analysis. SEM analysis is called covariance structure analysis because the analysis in the SEM models associated with a covariance matrix of the data (Bollen 1989; Ferdinand 2002).

Ghozali and Fuad (2005) stated that; the definition of SEM is a combination of 2 separated statistical method 


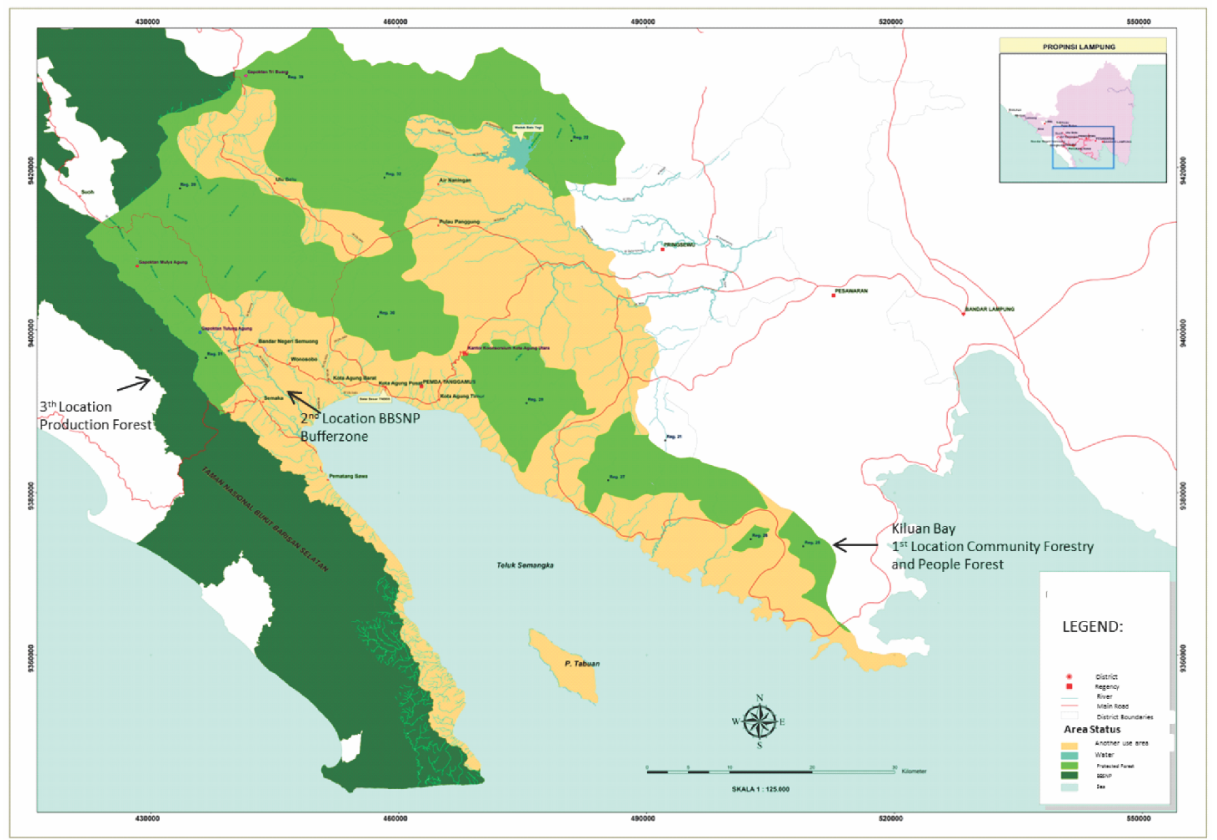

Source: Central Bureau of Statistics 2013.

Figure 1 Map of study site.

namely factor analysis developed in psychology and psychometrics with simultaneous equation modeling developed in econometrics. Technical analysis of SEM is an integrated approach between the factor analysis, structural modeling, and path analysis. On the other hand SEM is also an integrated approach between the analysis of the data and the concepts construction.

Brief descriptions of the model in Figure 2 are as follows: social entropy factors is composed of citizens trust (Y11), response to expectations on the farm owned (Y12), the availability of sideline opportunities (Y13), and the skepticism of local people (Y1). Social entropy is influenced by the social dimension of psychological, social, ecological, socio-economic and socio-cultural. Socio-psychological dimension is measured on the reaction of citizens in the face of the licensing process of tenure (X1), which consists of selfesteem factor (X11), non-formal education (X12) and the nobility of local people (X13). Socio-ecological dimension is measured on the carrying capacity of the land (X2), which consists of environmental ethics factor (X21), land area (X22), and land geophysical conditions (x23). This hypothesis obtained from the identification of potential irregularities that exist among the sites as described in appendix 1 .

Other variables that affect social deviation is the socioeconomic dimension. This variable is measured on the reaction of the citizens of the capital availability. Factors economic dimension consists of revenue mainstay (X31) measured from the preference of farmers to various existing sources of income, and the amount of revenue (X32) were obtained. Furthermore, the social dimension of culture, measured on the interest in the invitation for cooperation (X4), which consists of the attitude factor (X41), reciprocity (x42), customs and traditions (X43), network (X44), social norms (X45) and customary law (X46).
Identification of social entropy factors The inhabitant lifestyle socio-anthropologically would also refer all biogeophysical changes that occur. Once the human element comes into the cause of a various ecological changes (Tilman and Lehman 2001), ecological response to a new development will change human attitudes and behavior. These conditions give rise to the attitudes and behavior of socio-paradoxical (a positive response individually, but become a boomerang that is contradictive to the values of social society nobility; or vice versa).

Sjarkowi (2014) stated theoretically, such socioparadoxical phenomenon arises from 2 possibilities of human reactions. Those are; the individual positive response (I+) but become boomerang against the partnerships because precisely on the contrary to the noble values of society so that the social response becomes negative (S-). Also on the opposite order if positive response which is given by community $(\mathrm{S}+)$ not supported by some influential persons (i-). This social response always gives both positive and negative potency. The positive dominance over negative or otherwise are highly dependent on the anticipation of public decision makers in reducing various forms of potential social response negatively.

Identification results are presented in appendix 1 shows the paradoxical phenomenon that arises due to the driving factor. Sjarkowi (2014) states that the drivers can be traced through several dimensions of measurement; the dimension of socio-psychological, socio-ecological, socio-economic and socio-cultural. In the area of social forestry, the dimension of socio-psychology shows positive response signaled by the local people when the receive land management licensing assistance offered by NGOs and local authorities. They were highly expecting this assistance since the licensing process to be lengthy and convoluted to obtain the management permit issued by the Ministry of Forestry. 

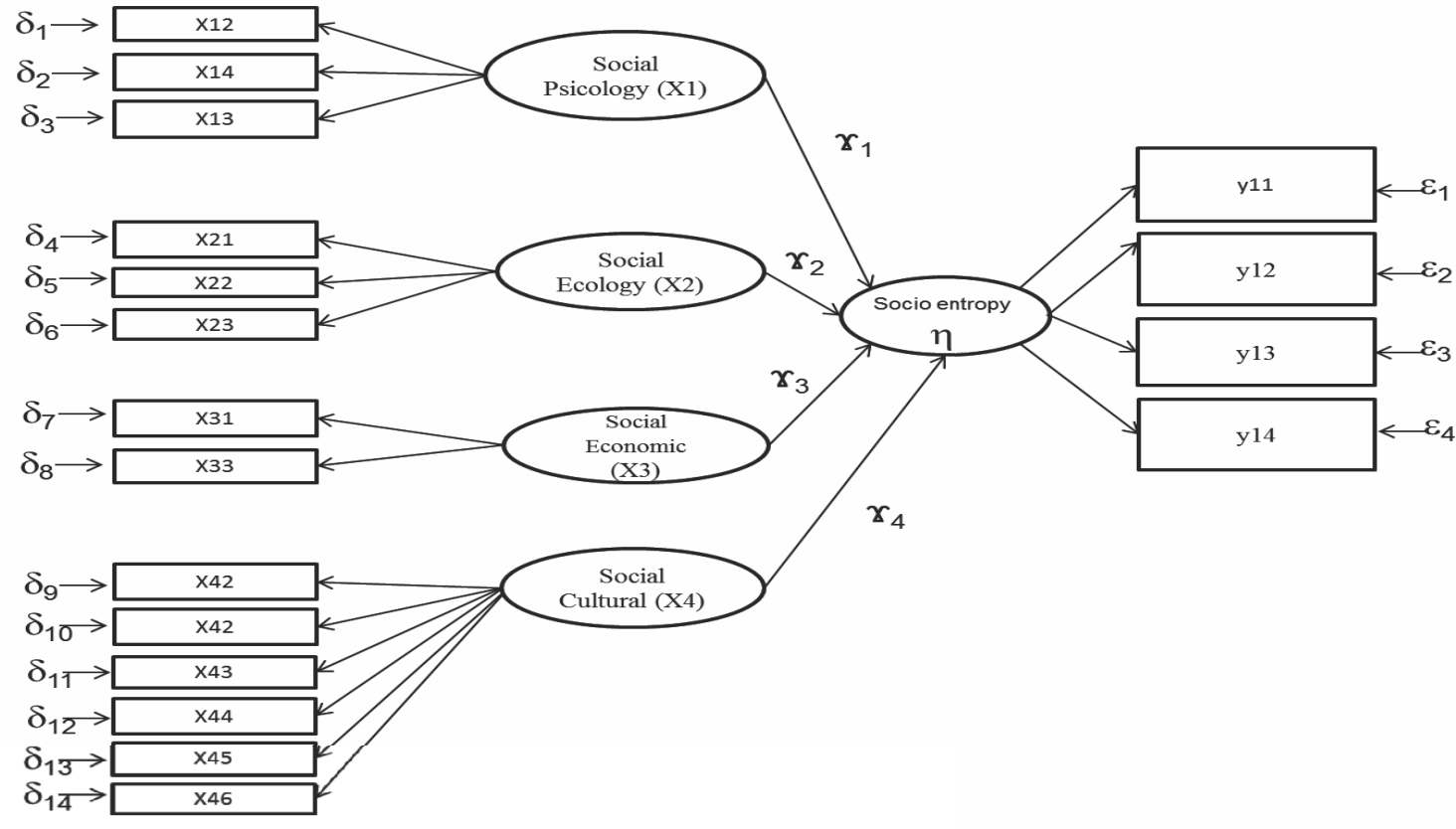

Legend:
Y11
Y12
Y13
X11
X13
X14
X21
X22

Community Trust Level score
Owned farming expectancy score
Alternative Bussincss Oppor-tunitics seizing
score
Self Esteem score
Non Formal education score
Community supremacy score
Environmental Ethics score
Land area score

$\begin{array}{ll}\text { X23 } & \text { Land geophysical condition score } \\ \text { X31 } & \text { Main Revenue score } \\ \text { X32 } & \text { Revenue value score } \\ \text { X41 } & \text { Attitude score } \\ \text { X42 } & \text { Resiprocity score } \\ \text { X43 } & \text { Indigenous Traditions score } \\ \text { X44 } & \text { Network score } \\ \text { X45 } & \text { Social Norms score } \\ \text { X46 } & \text { Customary Law score }\end{array}$

Figure 2 Hypothesized structural equation model for Socio-entropy system approach (SESA).

Otherwise negative response appereared due to some unscrupulous political leaders involved practical; licensing arrangement associated with the momentum of the political election, so as if the assistance given by certain leaders. This social paradox raised social deviation that indicated by the declining public trust in the leader or village officials.

The social dimension of social ecology showed a positive response in the event of a decline in production of forestry land with the emergence of citizen efforts to find alternative sources of income (Harris \& Sills 2005). This was demonstrated by the behavior of the people who start planting multiple crops, hoping that when the main crop production is no longer optimal, they still can have income from distraction plants. Yet the negative response followed to come in a row with efforts to expand the area for distraction crops such as bananas, without paying attention to the environmental issue, because there were logging of considered unproductive trees, or even open up new areas to grow crops that were considered more productive. This social paradox potentially trigger socio-entropy in the form of ego to take control of more land, because of declining production.

Positive social response demonstrated from socioeconomic dimension due to the diversity of business sectors that could be occupied as a source of additional income, such as trade and tourism (Scheyvens 1999; Setyadi et al. 2012). This phenomenon was good on the one hand because it can spur economic citizens. But on the other hand there came the negative reaction to the onset of the seizure of tourism business opportunities, and many farmers who doubles as middlemen. This social paradox potential to social deviation in the form of the struggle for a side business opportunities, either overtly or covertly potentially to cause discordance.

The socio-cultural dimension showed positive response within the arriving of new various tribes into the local community, (among others, Javanese, Sundanese, Balinese). Diversity was also shown by the openness of the natives to the diversity of customs and cultures brought from the place of origin. Differences in language, manners, religion and even provide color to the lives of the people (Rini et al. 2016). But this distinction was not always smooth sailing. Negative response arised when one of the parts get more successful in life that trigger jealousy, causing ethnicity. This condition requires the presence of a third party that can be trusted to bridge the differences. However, not all third parties were able to resolve the existing problems, instead they took advantages from the situation. This paradoxical situation has been growing apathetic of local people towards immigrants, especially partnership invitations, and increased suspicion of the programs offered, especially if in contact with indigenous issues.

Overall driving factors can be traced from intervening variables of each social dimensions, those are:

1 socio psychological dimension, consist of non formal education, individual compassion and self-esteem owned by each individual in the community. 
2 the socio ecological dimension including local wisdom factor in managing land traditionally/customarily and the spirit of owning more land plots, and the geomorphological position of owned land plots

3 the social dimension of the economy can be traced through the 2 intervening variables, the first is; alternative sources of income as the mainstay of each individual (farm, livestock, tourism, trade); second is the magnitude of the sources of mainstay individually income

4 intervening of socio-cultural variables dimension, consist of the existence of growing social capital in a region and that customs surrounding the various tribes contained in particular region.

Those various driving factors will cause different social paradox reaction that create potential social entropy among others:

1 decline of public trust levels in the leader of the region

2 widespread of land grabbing due to the declined production of farm land owned

3 seizure of alternative business opportunities; and

4 tendency to be apathetic to each invitation to work together, so that the community will be difficult to be fostered and directed.

Model of socio entropy system approach Analysis of the factors which determine the trigger of socio entropy was done by using SEM with the help of the LISREL 8.70 program. The final result is in the form of the track diagram as shown in Figure 2. Referring to the results of data analysis as presented in Figure 3, it is given objective information as follows: (1) the result of the suitability test of the model indicates that the model fit the data. This is indicated by the value of GFI $=0.9 \geq 0.9 ;$ RMSEA $=0.08 \leq 0.08$; and the value of CFI $=0.9 \geq 0.90$. (2) The test result on the significance of the estimated coefficient weighting factors are all significant at the level of error 5 percent with magnitude of estimations standardized entirely above 0.50 . Conclusion gained after eliminating non-valid and unreliable measurement indicators from the model, so that resulting model met the requirements of congeneric criteria measurement model, which means that variable studied is unidimensionalitas, valid, and reliable.

The relationship between the variables that are interpreted to describe the relationship of a variable with the other indicated by the values of load factors on the results of model estimation. The level of the relationship between variables in the model can be seen in the results of SEM analysis of the value of the standardized solution. Standardized Solution is a standard value diversity criteria $\leq|1|$. Figure 3 shows the overall value $\leq|1|$, so that diversity is good enough. Test results of the weighting factors can be interpreted from all five existing latent variables. Social ecological variables value which is the largest load factor has the strongest relationship to the forming of socio-entropy. While the other variables have a balanced relationship to the forming of socio entropy.

T-Test in the diagram (Figure 4) easily interprete the relationship between variables. If the value of $\mathrm{T}$-count $>\mathrm{T}$ table with $(\alpha) 0.05(\mathrm{~T}$-table $=1.96)$, it comes as a real effect or a significant variable to another variable. Figure 4. shows that the potential socio-entropy, is significantly affected by psychosocial factors at -3.32 , socio-ecological factors at 4,62 , socioeconomic factors of 3.61 and socio-cultural factors of 3.19. Factors of socio entropy are the level of trust of citizens, expectations of an existing farm, the existence of a business opportunity, and the apathy of citizens. Therefore, in order to defuse arising social unrest, the four factors should be fully considered.

Influence of socio psychological factor on the emergence of social entropy Figure 4 shows that three mainly affecting factors on socio psychological are self-esteem score variable $(\mathrm{X} 12=4.15)$, non-formal education score variable $(\mathrm{X} 13=-$ $6.61)$ and nobility of inhabitant score variable (X14 = 18.95). Self-esteem, non-formal education and nobility of the inhabitant (respect for others) factors are intervening variables of socio psychological condition arising from social dissatisfaction. At the location of the research, the trigger of social dissatisfaction began from the tenure of the land of different circumstances; in the area of community forest, triggered from protracted licensing, and the distribution of land that were not transparent. In the production forest area, it was triggered by obscurity ownership land which, production forest area that ever been controlled by residents today are owned by the government submitting the management to PT Andante. Along with the expiration of the license in controlling production forest, PT Andatu simply left the land, and the current land management is now taken over by the inhabitants. This uncertain condition makes the people come apathetic to a variety of policies and cooperation invitations.

Self-esteem factor (Mruk 2006) explains that the higher the social status and the respect from others, the more increase of the intervening psychosocial variables. Various studies explained that the self-esteem demonstrate the existence and egoism from someone (Abrams \& Hogg 2006). So the higher the score of self esteem of someone even trigger more potential dissatisfaction, because he feels more entitled to power and in terms of land tenure.

Non-formal education factor (Bhola 1983) derived from experience, observing the examples, and imitating the good deeds. This can be explained that more and more gaining experience in non-formal education will decrease the intervening socio-psychological variables. This happens because experience will increasingly form the thorough and mature mindset pattern, so he will not be easily provoked by frictions in the effort of land tenure. Factor of the nobility of the citizens is reflected in the attitude of respect for others; the higher attitude of respect for the others the lower psychosocial intervening variables that arise in the community. If every citizen tried to maintain an attitude of respect for others, it will be a psychological impact on society; the higher attitude of respect for others the lower intervening psychosocial variables that arise in the community. This factor is the most substantial influence on the psychological impact variables that are formed towards the land tenure process, amounting to -18.96 .

Influence of social- ecological factors on the emergence of 


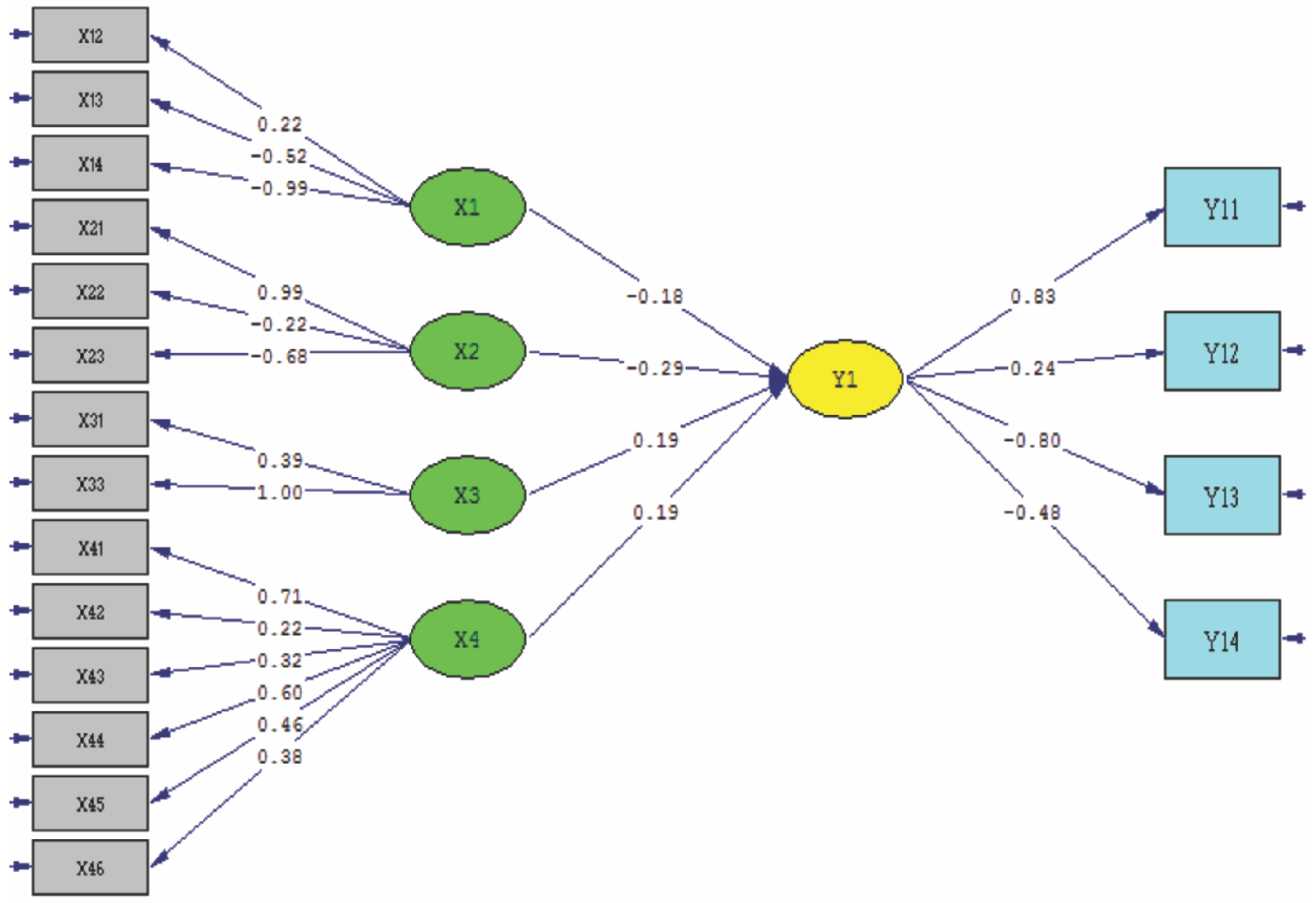

$\begin{array}{ll}\text { Legend: } & \\ \text { X1 } & \text { The social impact of psychological through the process of tenure } \\ \text { X2 } & \text { Social-ecological impact } \\ \text { X3 } & \text { The socio-economical impact of availability of capital } \\ \text { X4 } & \text { Socio-cultural impact to the partnership invitation } \\ \text { Y } & \text { Sosio-entropy } \\ \text { Y11 } & \text { Community trust level score } \\ \text { Y12 } & \text { seizing score } \\ \text { Y13 } & \text { Owned farming expectancy score Alternative bussiness oppor-tunities } \\ \text { X11 } & \text { Self esteem score } \\ \text { X13 } & \text { Non formal education score } \\ \text { X14 } & \text { Community supremacy score }\end{array}$

$\begin{array}{ll}\text { X21 } & \text { Environmental ethics score } \\ \text { X22 } & \text { Land area score } \\ \text { X23 } & \text { Land geophysical condition score } \\ \text { X31 } & \text { Main revenue score } \\ \text { X32 } & \text { Revenue value score } \\ \text { X41 } & \text { Attitude score } \\ \text { X42 } & \text { Resiprocity score } \\ \text { X43 } & \text { Indigenous traditions score } \\ \text { X44 } & \text { Network score } \\ \text { X45 } & \text { Social norms score } \\ \text { X46 } & \text { Customary law score }\end{array}$

Figure 3 Model diagram of social entropy estimation factors Standardized solution (SS).

social entropy Environmental ethics, land tenure, and geophysical conditions of land are socio ecological factors associated to carrying capacity of land which has real influence on the social entropy that arises in the community. Figure 4. shows three influential factors are the environment ethics variable score $(\mathrm{X} 21=18.15)$, the land expansion variable score $(\mathrm{X} 22=-3.48)$ and land geophysical condition score $(\mathrm{x} 23=-9.45)$.

Socio-ecological problem is reflected as far as concerns on the socio-anthropological aspects (Sjarkowi 2013). Ecological changes that caused by human behavior and activities in the long term will ultimately affect the socioecological change (Brunson 1993; Tilman \& Lehman 2001). This influence is basically the root of certain socio-ecological behavior of the people living in a specific geographic zone, as happened at the study site, the absence of control of land use is one factor in the decline of land use, and became one of the significant causes of social entropy.

Environmental ethics factor constitutes intervening variables of socio-ecological aspects which has a real positive influence on carrying capacity of the land. This factor was measured from the behavior/practices based on respondents' beliefs and understanding of the interrelationships between social systems of a person/ group and the conservation of the environment surrounding (Buckles 1999), as seen from their activities in the use of fertilizers, pesticides, land clearing and preparing method. The higher awareness in environmental conservation and wisdom in the use of chemicals will increase the carrying capacity of the land.

Land tenure factor is also an intervening variable of socio-ecological aspects which has real negative effect on the carrying capacity of the land. Lambin and Meyfroid (2010) states that land use transitions can be caused by negative socio-ecological feedbacks that arise from a depletion of key resources. The more land occupation that accompanied by a low understanding of forestry land use will more decrease progressively socio-ecological intervening of the land carrying capacity.

Geophysical forestry land condition in general is at slope area which is greater than $45^{\circ}$. Steep land slope condition and not accompanied by cultivation that has strong rooting, will further lower the fertility of the soil due to landslides and the leaching of nutrients in the rain. This is what happened in the 


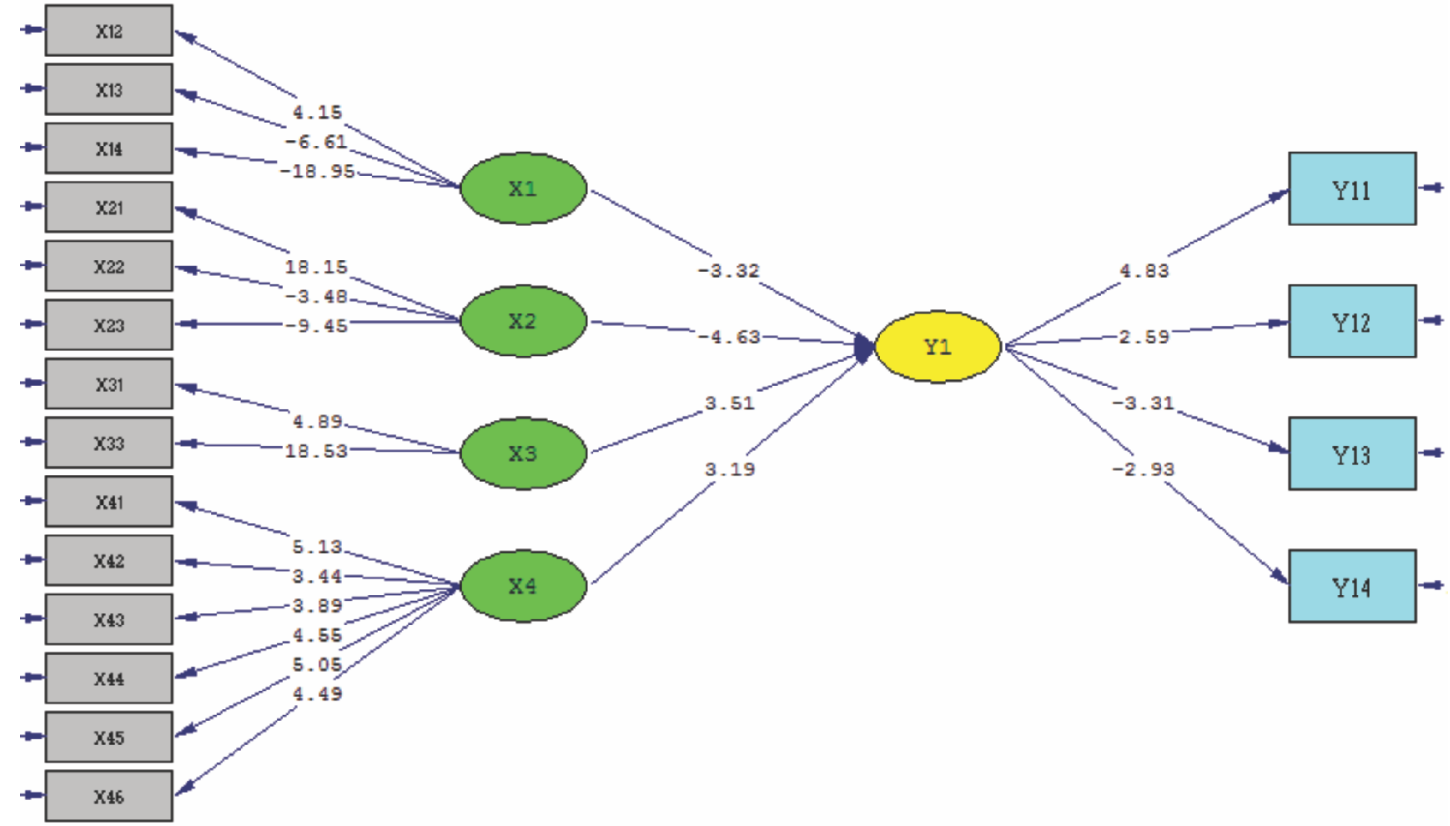

$\begin{array}{llll}\text { X1 } & \text { The social impact of psychological through the process of tenure } & \text { X21 } & \text { Environmental ethics score } \\ \text { X2 } & \text { Social-ecological impact } & \text { X22 } & \text { Land area score } \\ \text { X3 } & \text { The socio-economical impact of availability of capital } & \text { X23 } & \text { Land geophysical condition score } \\ \text { X4 } & \text { Socio-cultural impact to the partnership invitation } & \text { X31 } & \text { Main revenue score } \\ \text { Y } & \text { Sosio-entropy } & \text { X32 } & \text { Revenue value score } \\ \text { Y11 } & \text { Community trust level score } & \text { X41 } & \text { Attitude score } \\ \text { Y12 } & \text { Owned farming expectancy score Alternative bussiness oppor-tunities seizing } & \text { X42 } & \text { Resiprocity score } \\ \text { Y13 } & \text { score } & \text { X43 } & \text { Indigenous traditions score } \\ \text { X11 } & \text { Self esteem score } & \text { X44 } & \text { Network score } \\ \text { X13 } & \text { Non formal education score } & \text { X45 } & \text { Social norms score } \\ \text { X14 } & \text { Community supremacy score } & \text { X46 } & \text { Customary law score }\end{array}$

Figure 4 Model diagram of Socio entropy system approach based on T-Value.

whole area of research, so that land geophysical conditions will decrease socio-ecological intervening for the land carrying capacity.

The influence of socio economic factors on the emergence of social entropy Intervening variables in socio-economic variable consist of mainstay revenue source factor and the amount of revenue obtained. Results of the analysis shows in Figure 4. that the infulencing factors in socio-economic are mainstay revenue variable score $(\mathrm{X} 31=4.89)$ and income scale variable score $(x 33=18.53)$. All respondents derived positive benefits from forestry land which were owned. Yet, there is actually driving factor to trigger social paradox that give rise to kind of socio-economic entropy which may prevent people in providing positive appreciation (Sjarkowi 2014).

The interview result shows, all farmers have great hope and suspend the sources of income from multi purpose tree species (a.l. cocoa, coffee, cloves, banana), although land productivity has decreased. This condition encourages farmers to look for alternative sources of revenue in odd jobs to survive, such as trade and become farm workers. In some places with fortunately tourism potential, they used it as a new revenue as well. This causes seizure for a side job opportunity in order to survive, even some of local people frequently make the income derived from the side job to be capital for farming, such as for the purchase of fertilizers and plants chemical. This means the higher community expectation in farming as countable income precisely raise intervening socio-economy variable on capital availibility, so that raise the socio-entropic potential.

Another issue which should be considered as a causal factor is that the state forest land is a public good (good or object in this research is a state forest land), managed by the state for the maximum used by the outsider community, without segmenting benefits for certain groups exclusively as a private good. Unfortunately it is often interpreted narrowly that in practice the state forest "exploited" by users (citizens, companies, and others) with the assumption that the event of exploitive damage is the responsibility of the government to recover. If the condition continues, it then happens is a real example of public land conflict in natural resource management (Solberg \& Miina 1997).

Influence of social-cultural factors on the emergence of social entropy Measured from socio-cultural perspective that is necessary to tame the social aberrations that arise. Society needs to preserve the cultural and social capital, as occurs in some indigenous communities in other regions (Iswandono et al. 2015), not only for the sake of lifting their 
economic well-being directly but also those indirectly. Actions irregularities committed by an individual such as any form of corruption or misappropriation of village officials were able to be inhibitation and trigger tribal sentiments that raise suspicions among locals.

Intervening socio cultural variable related to cooperation invitation has a real influence on social entropy that arises. Figure 4 shows that intervening socio cultural factors associated to attitude $(X 41=5,13)$, reciprocity $(X 42=3,44)$, customs $(\mathrm{X} 43=3,89)$ and tradition $(\mathrm{X} 44=4,55)$, social norm $(\mathrm{X} 45=5,06)$ and customary law $(\mathrm{X} 46=4,49)$ positively influence the willingness of cooperation invitation. Of the six factors, attitudes and networks is the most dominant factor in shaping the socio-cultural variables. According Abrams and Hogg (2006), the attitude can be defined into three categories, namely; (a) oriented to the response; attitude is a form of feeling, the feeling of support (favorable) as well as the feeling of not supporting the (unfavorable) on an object, (b) oriented to response preparedness; an attitude of readiness to react to an object in a certain way, when faced with a stimulus that calls for a response, a behavior pattern, and anticipatory readiness to adapt to the social situation that has been conditioned, (c) oriented to triadic schemes; attitude is a constellation of components of cognitive, affective and conative interacting in understanding something, feel and behave towards an object in its environment. Manifestation of the attitude shown by the tendency of farmers to accept and open to others.

Network is defined as human nature as social beings that can not be removed from the community independently. No human being can stand alone do any activity to meet his needs without the assistance of others. It is as stated by Robinson (1998) that the unit of the lower layers of society organizations (grassroots communities) should form a group because rural communities can not function as an autonomous individual. When individuals stretched from the community (both social and natural environment) they are easily swayed by outside forces thereby reducing their effectiveness in achieving collective activities and interests that ultimately their bargaining position in the fight for their interests will be weakened.

Social entropy factors Social entropy factors consist of three indicator; level of people trust score (Y11), expectations of farms owned score (Y12), seizing of alternative business opportunities score (Y13) and apathy of people score (Y14). Figure 3. shows the load factor is owned by Y51 variable of 0.83 . The smallest load factor owned by a variable expectations score of farming (Y12), is thought to be caused by the fact that this factor is very instrumental, so that when the expectations of the farm owned is decreasing then it would bring diversions.

Meanwhile factors of seizing business opportunities and apathy have a negative charge in socio-entropy, which means that more diverse business opportunities that done then it will further decrease the socio-entropy, can explain that a lot of business opportunities taken by the people will increasingly make them busy, and not easily ignited for supporting social deviation.

\section{Conclusion}

Each progress level in social forestry development management comes leaned to such social paradox followed by socio-entropy appearance. So, to anticipate this potential entropy it is would be taken approachment through four social dimension, namely socio-psychological, socioecological, socio-economical and socio-cultural. Anticipations can be done through some influential factors in the social dimension. In socio-psychological dimension there needed efforts to improve local people's self esteem and nobility while providing non-formal education in the management target communities. On the social and ecological dimension it is necessary to raise public awareness on environmental ethics, and also to increase local awareness to stop expand the land by a land clearing in protected areas, as well as giving understanding of land management methods in the contoured geophysical conditions. On the socio-economic dimension there necessarily given the solution of alternative incomes that can be used as additional source of mainstay revenue to increase the amount of income earned by farmers. On the sociocultural dimension there needed the social capital strengthening. Social capital is consist of factors: attitude, reciprocity, customs, traditions, networks, social norms and customary law. Overall social dimension factors are truly significant in the socio-entropy so that become the reason of a social forestry management failure besides the technical aspects of management that assumed to run well.

\section{Recommendation}

Every forest-management program supposed to take good comprehensive attention on the social dimensions of a community. This is intended to minimize the potentially failure in the management. And give expediency towards related stakeholder, farmers, partners and government as well.

\section{References}

Abrams D, Hogg MA. 2006. Comments on the motivational status of self esteem in social identity and intergroup discrimination. European Journal of Social Psychology 18(4):317-334. http://dx.doi.org/10.1002/ejsp.2420180 403.

Bala G, Caldeira K, Wickett M, Phillips TJ, Lobell DB, Delire C, Mirin A. 2007. Combined climate and carboncycle effects of large-scale deforestation. Proceedings of the National Academy of Sciences 104(16):9911-9911. http://dx.doi.org/10.1073/pnas.0608998104.

Bhola, Harbans S. 1983. Non-formal education in perspective. Prospects - Quarterly Review of Educatio (Non-formal Education Resources)1(45):13-18.

BMZ. 1995. Environmental Handbook; Documentation on Monitoring and Evaluating Environmental Impact. Vol. II. Germany: Friedrich Vieweg and Sohn Publishing.

Buckles D. 1999. Cultivating Peace; Conflict and 
Appendix 1 Identification of various social factors that potentially lead to social entropy

\begin{tabular}{|c|c|c|c|c|c|c|}
\hline \multirow{2}{*}{$\begin{array}{l}\text { Entrophy } \\
\text { social } \\
\text { dimension }\end{array}$} & \multirow[t]{2}{*}{ Location } & \multirow{2}{*}{$\begin{array}{c}\text { Factors encouraging } \\
\text { social discontent } \\
\text { that lead to } \\
\text { S-paradox }\end{array}$} & \multirow{2}{*}{$\begin{array}{c}\text { Intervening } \\
\text { variable }\end{array}$} & \multicolumn{2}{|c|}{ Social reaction pa radox } & \multirow{2}{*}{$\begin{array}{l}\text { Potency } \\
\text { entrophy } \\
\text { social } \\
\text { arising }\end{array}$} \\
\hline & & & & Reaction (+) & Reaction (-) & \\
\hline \multirow{3}{*}{$\begin{array}{l}\text { Socio- } \\
\text { psychological }\end{array}$} & $\begin{array}{l}\text { Community } \\
\text { forest }\end{array}$ & $\begin{array}{l}\text { - The process of licensing } \\
\text { protracted } \\
\text { - The distributions of land } \\
\text { that are not transparent }\end{array}$ & $\begin{array}{l}\text { Negotiations factor: } \\
\text { - education } \\
\text { - self esteem } \\
\text { - nobleness of }\end{array}$ & $\begin{array}{l}\text { Help acceleration of } \\
\text { licensing through NGOs } \\
\text { and local district } \\
\text { government }\end{array}$ & $\begin{array}{l}\text { People forest permission } \\
\text { become a political } \\
\text { commodity for elections } \\
\text { and local police officers }\end{array}$ & \multirow{3}{*}{$\begin{array}{l}\text { Declining } \\
\text { public } \\
\text { confidence } \\
\text { in leaders }\end{array}$} \\
\hline & People forest & $\begin{array}{l}\text { - The distributions of aid } \\
\text { production facilities } \\
\text { uneven }\end{array}$ & $\begin{array}{l}\text { citizens in the form } \\
\text { of respect for others }\end{array}$ & $\begin{array}{l}\text { Looking for alternative } \\
\text { businesses in addition to } \\
\text { Farming }\end{array}$ & $\begin{array}{l}\text { People unmanaged forest } \\
\text { areas, and the farm } \\
\text { opportunities are not } \\
\text { exploited }\end{array}$ & \\
\hline & $\begin{array}{l}\text { Production } \\
\text { Forest }\end{array}$ & $\begin{array}{l}\text { - Violation of a } \\
\text { cooperation agreement } \\
\text { made by investors } \\
\text { - Obscurity land ownership } \\
\text { status }\end{array}$ & & $\begin{array}{l}\text { Replacing the wood with } \\
\text { a rubber plant that has a } \\
\text { better sale value }\end{array}$ & $\begin{array}{l}\text { Reforestation efforts } \\
\text { due to deforestation to } \\
\text { be in vain }\end{array}$ & \\
\hline \multirow{3}{*}{$\begin{array}{l}\text { Socio- } \\
\text { ecological }\end{array}$} & $\begin{array}{l}\text { Community } \\
\text { forest }\end{array}$ & $\begin{array}{l}\text { - Pests and climate } \\
\text { change } \\
\text { - Rules for composition } \\
60: 40 \text { between the plant } \\
\text { canopy height: medium } \\
\text { crown }\end{array}$ & \multirow{3}{*}{$\begin{array}{l}\text { Efficiency factor } \\
\text { - environmental } \\
\text { ethics } \\
\text { - the area of forest } \\
\text { land controlled } \\
\text { - land geophysical } \\
\text { conditions }\end{array}$} & $\begin{array}{l}\text { Multi crops efforts with } \\
\text { bananas and cash crop } \\
\text { plant }\end{array}$ & $\begin{array}{l}\text { Forest function declines, } \\
\text { increased erosion } \\
\text { opportunities }\end{array}$ & \multirow{3}{*}{$\begin{array}{l}\text { The } \\
\text { widespread } \\
\text { seizure of } \\
\text { land for } \\
\text { business }\end{array}$} \\
\hline & people Forest & $\begin{array}{l}\text { - Vacant land } \\
\text { - There are many shifting } \\
\text { business priorities }\end{array}$ & & $\begin{array}{l}\text { Many business sectors that } \\
\text { could be occupied, ex: } \\
\text { ecotourism, trade }\end{array}$ & $\begin{array}{l}\text { land abandoned, } \\
\text { because the shift of } \\
\text { concentration of effort }\end{array}$ & \\
\hline & $\begin{array}{l}\text { Production } \\
\text { Forest }\end{array}$ & $\begin{array}{l}\text { - Low soil fertility } \\
\text { - The many variations of } \\
\text { the annual crop is the } \\
\text { motivation to change the } \\
\text { type of plant that belongs } \\
\text { today }\end{array}$ & & $\begin{array}{l}\text { There are various sources } \\
\text { of revenue from oil, rubber, } \\
\text { and timber }\end{array}$ & $\begin{array}{l}\text { Do not focus on a } \\
\text { single farm because } \\
\text { overshadowed the } \\
\text { advantages of this type } \\
\text { of farm that it is not } \\
\text { owned }\end{array}$ & \\
\hline \multirow[b]{3}{*}{$\begin{array}{l}\text { Social- } \\
\text { economical }\end{array}$} & $\begin{array}{l}\text { Community } \\
\text { forest }\end{array}$ & $\begin{array}{l}\text { - Minimal capital } \\
\text { - Unlimited business } \\
\text { opportunities }\end{array}$ & \multirow{3}{*}{$\begin{array}{l}\text { Factor income } \\
\text { - revenue mainstay } \\
\text { - the amount of } \\
\text { revenue }\end{array}$} & $\begin{array}{l}\text { Further expand the planting } \\
\text { area and replace the entire } \\
\text { forestry crops with cocoa }\end{array}$ & $\begin{array}{l}\text { The loss of revenue } \\
\text { opportunities from } \\
\text { annual plants (NTFPs) }\end{array}$ & \multirow{3}{*}{$\begin{array}{l}\text { Seizure of } \\
\text { alternative } \\
\text { business } \\
\text { opportunitie } \\
\mathrm{s}\end{array}$} \\
\hline & People forest & $\begin{array}{l}\text { - Limitations if the } \\
\text { capital for land } \\
\text { - The number of business } \\
\text { opportunities from } \\
\text { ecotourism sector }\end{array}$ & & $\begin{array}{l}\text { The income from the } \\
\text { source of great tourist } \\
\text { value and is cash money }\end{array}$ & $\begin{array}{l}\text { There is no alternative } \\
\text { source of income when } \\
\text { the tourism sector is on } \\
\text { the decline, the land does } \\
\text { not produce }\end{array}$ & \\
\hline & $\begin{array}{l}\text { Production } \\
\text { forest }\end{array}$ & $\begin{array}{l}\text { - Marketing of timber } \\
\text { harvests are not in } \\
\text { accordance with the } \\
\text { partnership agreement } \\
\text { with plywood factory } \\
\text { - The remote location, } \\
\text { resulting in low crop } \\
\text { prices received by } \\
\text { farmers }\end{array}$ & & $\begin{array}{l}\text { The number of farmers } \\
\text { who doubles } \\
\text { as traders. }\end{array}$ & $\begin{array}{l}\text { Competition among } \\
\text { traders }\end{array}$ & \\
\hline \multirow{3}{*}{ Socio-cultural } & $\begin{array}{l}\text { Community } \\
\text { forest }\end{array}$ & $\begin{array}{l}\text { - Different ethnic origin } \\
\text { causes cultural differences }\end{array}$ & \multirow{3}{*}{$\begin{array}{l}\text { Factors cooperation } \\
\text { - attitude } \\
\text { - reciprocity } \\
\text { - indigenous culture } \\
\text { - network } \\
\text { - social norms } \\
\text { - customary law }\end{array}$} & $\begin{array}{l}\text { The existence of the } \\
\text { guidance of some NGOs } \\
\text { to bridge relationships } \\
\text { with leaders }\end{array}$ & $\begin{array}{l}\text { Further reduces trust in } \\
\text { the leader and become a } \\
\text { dependency with third } \\
\text { parties }\end{array}$ & \multirow{3}{*}{$\begin{array}{l}\text { Tend to be } \\
\text { apathetic in } \\
\text { addressing } \\
\text { immigrant } \\
\text { solicitation } \\
\text { partner }\end{array}$} \\
\hline & People forest & $\begin{array}{l}\text { - Natives feel more } \\
\text { powerful but lacks the } \\
\text { ability to manage } \\
\text { resources }\end{array}$ & & $\begin{array}{l}\text { The inclusion of diverse } \\
\text { cultures ex: Balinese, } \\
\text { Sundanese, Javanese with } \\
\text { the peculiarities of each }\end{array}$ & $\begin{array}{l}\text { Requires traditional } \\
\text { leaders who can regrow } \\
\text { confidence of the } \\
\text { inhabitants }\end{array}$ & \\
\hline & $\begin{array}{l}\text { Production } \\
\text { forest }\end{array}$ & $\begin{array}{l}\text { - Does not have any role } \\
\text { models/leaders respected } \\
\text { - The organization away } \\
\text { from the group, because } \\
\text { considered unprofitable }\end{array}$ & & $\begin{array}{l}\text { Land management is } \\
\text { done independently and } \\
\text { not interdependent }\end{array}$ & $\begin{array}{l}\text { The difficulty for } \\
\text { cooperative and village } \\
\text { consultation }\end{array}$ & \\
\hline
\end{tabular}


Collaboration in Natural Resources Management. International Development Research Center (IDRC) in Collaboration with The World Bank Institute. Ottawa: International Development Research Center (IDRC) in Collaboration with The World Bank Institute.

Bollen KA. 1989. Structural Equations with Laten Variables. New York: A Wiley-Interscience Publication. Jhon Wiley and Son.

Bonan GB. 2008. Forests and climate change: Forcings, feedbacks, and the climate benefits of forests. Science 320(5882):1444-1449. http://dx.doi.org/10.1126/ science.1155121.

Brunson MW. 1993. Socially acceptable forestry: What does it imply for ecosystem management? Western Journal of Applied Forestry 8(4):116-119.

Claussen M, Brovkin V, Ganopolski A. 2001. Biogeophysical versus biogeochemical feedbacks of large-scale land cover change. Geophysical Research Letters 28(6):1011-1014. http://dx.doi.org/10.1029/ 2000 GL012471.

Doliscaa F, Douglas RC, Joshua MM, Dennis AS, Curtis MJ. 2006. Factors influencing farmers' participation in forestry management programs: A case study from Haiti. Forest Ecology and Management 236(2-3):324-331. http://dx.doi.org/10.1016/j.foreco.2006.09.017.

Failing L, Gregory R. 2003. Ten common mistakes in designing biodiversity indicators for forest policy. Journal of Environmental Management 68(2):121-132. http://dx.doi.org/10.1016/S0301-4797(03)00014-8.

Farber, Stephen C, Costanza R, Matthew AW. 2002. Economic and ecological concepts for valuing ecosystem services. Special Issue: The Dynamics and Value of Ecosystem Services: Integrating Economic and Ecological Perspectives. Ecological Economics 41(3):375-392. http://dx.doi.org/10.1016/S0921-8009 (02)00088-5.

Ferdinand. 2002. Structural Equation Modeling (SEM) dalam Penelitian Manajemen. Program Magister Manajemen Universitas Diponegoro. Semarang: Badan Penerbit Universitas Diponegoro.

Fraser, Evan DG, Dougill AJ, Mabee WE, Reed M, Alpine PM. 2006. Bottom up and top down: Analysis of participatory processes for sustainability indicator identification as a pathway to community empowerment and sustainable environment management. Journal of Environmental Management 78(2):114-127. http://dx.doi.org/10.1016/j.jenvman.2005.04.009.

Gozali F. 2005. Structural Equation Modeling: Teori, Konsep dan Aplikasi dengan Program LISREL 8.54. Semarang: Badan Penerbit Universitas Diponegoro.
Harris, Caviglia JL, Sills EO. 2005. Land use and income diversification: comparing traditional and colonist populations in the Brazilian Amazon. Agricultural Economics 32(3):221-237. http://dx.doi.org/10.1111/ j.1574-0862.2005.00238.x.

Iswandono E, Zuhud EAM, Hikmat A, Kosmaryandi N. 2015. Integrating local culture into forest conservation: A case study of the Manggarai tribe in Ruteng Mountains, Indonesia. Jurnal Managemen Hutan Tropika 21(2):55-64. http://dx.doi.org/10.7226/jtfm.21.2.55.

Jöreskog K, Sörbom D. 2001. LISREL® 8.50. Chicago: SSI Scientific Software International.

Lambin EF, Meyfroidt P. 2010. Land use transitions: Socioecological feedback versus socio-economic change. Journal Land Use Policy 27(2):108-118. http://dx.doi. org/10.1016/j.landusepol.2009.09.003.

Levang E, Dounia, Sitorus S. 2005. Out of forest, out of poverty? Forests, Trees and Livelihoods 15:211-235.

Mruk Chistoper J. 2006. Self-Esteem Research, Theory, and Practice: Toward a Positive Psychology of Self-Esteem. USA: Springer Publishing Company, Inc.

Nurtjahjawilasa, Kartodiharjo H, Nurrochmat DR, Justianto A. 2015. The performance of forestry human resources in licensing forest utilization, the lease of forest area, and the release of forest area. Jurnal Management Hutan Tropika 21(2):76-82. http://dx.doi.org/10.7226/ jtfm.21.2.76.

Pagiola S, Ritter K, Bishop J. 2004. Assessing the Economic Value of Ecosystem Conservation. In collaboration with The Nature Conservancy and IUCN-The World Conservation Union. USA.

Pearce DW. 2002. The economics value of forest ecosystems. Ecosystem Health 7(2):284-296.

Rahmat S. 2002 Peluang dan tantangan Pengelolaan Hutan Kemasyarakatan di Propinsi Lampung. Bandar Lampung: Buletin Kampung. Watala Press.

Reyes T. 2008. Agroforestry systems for sustainable livelihoods and improved land management in the East Usambara Mountains [dissertation]. University of Helsinki: Tanzania.

Rini ES, Ali I, Yustina SE. 2015. Perubahan upacara adat perkawinan pada masyarakat sunda di Pekon Way Gelang. PESAGI (Jurnal Pendidikan dan Penelitian Sejarah) 3(6):12.

Robinson EC. 1998. Greening at The Grassroots; Alternative Forestry Strategies in India. London: Sage Publications. 
Scheyvens R. 1999. Case study ecotourism and the empowerment of local communities. Tourism Management 20(2):245-249. http://dx.doi.org/10. 1016/ S0261-5177(98)00069-7.

Setyadi IA, Hartoyo, Maulana A, Muntasib EKSH. 2012. Strategi pengembangan ekowisata di Taman Nasional Sebangau Kalimantan Selatan. Jurnal Manajemen Agribisnis 9(1):1-12.

Sjarkowi F. 2007. Lesson learned of private sector experiences on community partnership for plantation forestry. Jurnal Satuan Usaha Perhutanan Kerakyatan 1(1):5-12.

Sjarkowi F. 2014. Agroekosistem Sustainable Wetlands; The Statutes Innovation Food Sovereignty and Agriculture Society Welfare. Palembang: Baldad Grafiti Press.

Stankey GH, Bormann BT, Ryan C, Shindler B, Sturtevant V, Clark RN, Philpot C. 2003. Adaptive management and the northwest forest plan: Rhetoric and reality. Journal of Forestry 101(1):40-46.
Solberg B, Miina S. 1997. Conflict Management and Public Participation in Land Management. Finland: European Forest Institute.

Tilman David, Lehman C. 2001. Human-caused environmental change: impacts on plant diversity and evolution. Proceedings of The National Academy of Sciences of The USA. May 8, 2001. 98(10):5433-5440. http://dx.doi.org/10.1073/pnas.091093198.

Veron R. 2001. The "new" Kerala model: Lessons for sustainable development. World Development Journal 29(4):601-617. http://dx.doi.org/10.1016/S0305750X(00)00119-4.

Walt BD. 1985. Farming systems research: Anthropology, sociology, and farming Systems Research. Human Organization: Summer 44(2):106-114. http://dx.doi.org/ 10.17730/humo.44.2.d26r461892228g44.

Westoby JC. 1975. Changing Objectives of Forest Management. New Delhi: Asses to Ninth Commonwealth Forestry Conference.

Wiersum KF. 1984. Developing Strategies for Social Forestry: A Conceptual Approach. Working paper Environment and Policy Institute East West Center, Honolulu. 